\title{
ANALISIS PERBANDINGAN ASAM URAT BERDASARKAN POLA MAKAN PADA VEGETARIAN DAN NON VEGETARIAN DI MINAHASA
}

\author{
ANALYSIS OF COMPARISON OF URIC ACID BASED ON EAT PATTERNS \\ IN VEGETARIAN AND NON VEGETARIAN IN MINAHASA
}

\section{Priscillia Saluy}

Fakultas IImu Keperawatan, Universitas Klabat

E-mail:psaluy@yahoo.com

\begin{abstract}
ABSTRAK
Pendahuluan: Asam urat adalah bagian dari metabolisme purin, namun apabila tidak berlangsung secara normal maka akan terjadi sebuah proses penumpukan kristal dari asam urat pada persendian yang bisa mengakibatkan rasa sakit yang cukup tinggi. Konsumsi purin yang terdapat dalam daging dan seafood berhubungan terhadap resiko peningkatan kadar asam urat, sedangkan produk susu dapat menurunkan resiko asam urat dan konsumsi purin dari tumbuhtumbuhan tidak berpengaruh terhadap resiko asam urat. Tujuan: Tujuan penelitian ini untuk mengetahui perbandingan nilai asam urat berdasarkan pola makan pada vegetarian dan non vegetarian di Minahasa. Metode: Desain penelitian menggunakan case control dengan metode purposive sampling, dengan uji statistik $T$-test independent untuk melihat perbedaan kadar asam urat antara kedua kelompok dan ANOVA untuk analisis berdasarkan pola makan. Sampel dalam penelitian berjumlah 37 orang yang vegetarian dan 37 orang yang non vegetarian. Hasil: Hasil penelitian yaitu terdapat perbedaan yang signifikan kadar asam urat pada kelompok vegetarian dan non vegetarian dengan nilai $p$ value $=0,001<0,05$ dan berdasarkan pola makan tidak ada perbedaan yang signifikan kadar asam urat dengan nilai $p$ value $=0,856>0.05$. Diskusi: Kesimpulan penelitian ini hanya terdapat perbedaan yang signifikan kadar asam urat pada kelompok vegetarian dan non vegetarian sedangkan pola makan tidak ada perbedaan.
\end{abstract}

Kata kunci: Asam Urat, Pola Makan, Vegetarian, Non-Vegetarian.

\begin{abstract}
Introduction: Gout (gout) is part of purine metabolism, but if it does not take place normally there will be a process of crystalline buildup of uric acid in the joints which can cause quite high pain. Consumption of purines found in meat and seafood is related to the risk of increasing uric acid levels, while dairy products can reduce the risk of gout and consumption of purines from plants does not affect the risk of gout. Purpose: The purpose of this study is to know the comparison value of uric acid level according the eat pattern between the vegetarian and non vegetarian in Minahasa. Method: Research design using Ttest independent and ANOVA. The total sample is 37 respondents who vegetarian and 37 responden who non-vegetarian. Results: The result of this study is there is a significant relationship of uric acid level between vegetarian and non vegetarian with significant value 0,001<0,05 and according to the eat pattern there is no significant relationship of uric acid level with the significant value 0,856>0,05. Discussion: Conclusion of this study only there is a significant relationship of uric acid level between vegetarian and non vegetarian whereas eat pattern there is no significant telationship.
\end{abstract}

Key words: Uric Acid, Eat Pattern, Vegetarian, Non Vegetarian.
JURNAL

SKOLASTIK

\section{KEPERAWATAN}

Vol, 5, No. 1

Januari - Juni 2019

ISSN: $2443-0935$

E-ISSN $2443-16990$ 


\section{PENDAHULUAN}

Asam urat (gout) adalah bagian dari metabolisme purin, namun apabila tidak berlangsung secara normal maka akan terjadi sebuah proses penumpukan kristal dari asam urat pada persendian yang bisa mengakibatkan rasa sakit yang cukup tinggi. Sebenarnya asam urat sudah ada pada tubuh kita dan bukan suatu penyakit, asalkan asam urat tersebut dalam nilai yang normal. Sendi-sendi yang diserang terutama yaitu jari-jari kaki, tumit, pergelangan tangan, jari tangan dan siku. Selain nyeri, penyakit asam urat juga dapat membuat persendian membengkak, meradang, panas dan kaku, kadangi-kadang disertai pembentukan kristal natrium urat besar yang dinamakan tophus, deformitas (kerusakan) sendi secara kronis (Salma, 2007 \& Naga, 2013).

Sekitar $90 \%$ penyakit asam urat disebabkan oleh ketidakmampuan ginjal membuang asam urat secara tuntas dari tubuh melalui air seni. Sebagian kecil lainnya karena tubuh memproduksi asam urat secara berlebihan. Asam urat bisa terjadi akibat peningkatan asupan makanan yang tinggi purin (Naga, 2013). Makanan tinggi purin dari produk hewani seperti sardine, hati ayam, hati sapi, ginjal sapi, otak, daging, herring, mackerel, unggas, ikan, akan dapat meningkatkan kadar asam urat, apalagi bila hampir setiap hari dikonsumsi dalam jumlah berlebihan (Kanbara, 2010).

Konsumsi purin yang terdapat dalam daging dan seafood berhubungan terhadap resiko peningkatan kadar asam urat, sedangkan produk susu dapat menurunkan resiko asam urat dan konsumsi purin dari tumbuh-tumbuhan tidak berpengaruh terhadap resiko asam urat. Konsumsi karbohidrat kompeks seperti nasi, roti, ubi jalar dan ketela dapat memicu pembuangan kelebihan asam urat dalam darah (Sustrani, 2004).

Pola makan vegetarian mulai semakin diminati oleh masyarakat di negara maju maupun berkembang. Saat ini gaya hidup vegetarian mulai menjadi pilihan di masyarakat dengan alasan menginginkan pola hidup yang sehat atau untuk kesehatan, peduli akan lingkungan dan kesejahteraan hewan, alasan ekonomi, pertimbangan etik, persoalan kelaparan dunia dan dalam hal spiritual (Bangun, 2003; Craig \& Mangels 2009).

Penyakit asam urat dapat dijumpai disetiap negara di dunia. Hasil penelitian epidemologis menunjukkan bahwa bangsa Maori di Selandia Baru, Filipina, dan bangsa-bangsa dikawasan Asia Tenggara mempunyai kecenderungan menderita penyakit ini. Masyarakat Indonesia, suku Minahasa dan Tapanuli berpeluang menderita penyakit gout lebih tinggi dibandingkan dengan suku-suku yang lainnya (Junaidi, 2013). Penduduk daerah Minahasa memiliki prevalensi tinggi untuk mendapatkan penyakit asam urat karena erat hubungannya denganbudaya dan pola makan yang gemar mengkonsumsi makanan laut tertentu (Wurangian, Kepel \& Manampiring, 2013).

Tinjauan Pustaka Naga (2013) menuliskan asam urat atau gout berasal dari bahasa Latin yaitu Gutta yang 
artinya tetesan (luka yang jatuh tetes demi tetes ke dalam sendi). Asam urat merupakan sebuah penyakit dimana terjadi penumpukan asam urat dalam tubuh secara berlebihan, baik akibat produksi yang meningkat pembuangan yang menurun atau akibat peningkatan asupan makanan yang kaya purin. Penyakit asam urat di klasifikasikan menjadi dua yaitu primer dan sekunder:

\section{Asam urat primer}

99\% penyebabnya belum diketahui (idiophatik), namun kombinasi faktor genetik dan hormon diduga menjadi penyebab terganggunya metabolisme. Dapat juga diakibatkan karena berkurangnya pengeluaran asam urat dari tubuh.

\section{Asam urat sekunder}

Penyebabnya antara lain komplikasi dari hipertensi, artherosklerosis, diabetes dan mengkonsumsi makanan dengan kadar purin yang tinggi. Purin adalah senyawa basa organik yang menyusun asam nukleat (asam inti sel) dan termasuk dalam kelompok asam amino, unsur pembentuk protein.

Pada penelitian yang dilakukan oleh Hapendatu, Assa dan Paruntu (2016) menunjukkan hasil dari 25 responden vegetarian lacto-ovo yang hanya mengonsumsi produk nabati ditambah susu dan telur terdapat 7 orang $(28 \%)$ yang mempunyai kadar asam urat yang tinggi dan sisanya 18 orang $(72 \%)$ memiliki kadar asam urat dalam batas normal. Hasil ini mendukung teori gizi vegetarian yaitu kebutuhan makanan yang di konsumsi vegetarian di atur dalam piramida vegetarian yang berbeda dengan piramida makanan non vegetarian (Department of Nutrition Loma Linda University, 2008).

Bertolak belakang dengan hasil penelitian Himma dan Subagio (2008), didapati bahwa tidak ada hubungan antara asupan makanan yang mengandung purin dengan vegetarian. Hasil penelitian ini diperkirakan karena sumber purin yang di konsumsi berasal dari nabati. Produk nabati merupakan produk makanan yang berasal dari tumbuhan.

Dalam penelitian Setriani, Utari, Mardatilah, Wahyu dan Sudiarti (2013) pada vegan dan vegetarian lacto-ovo makanan yang dikonsumsi vegetarian dapat tercukupi sesuai dengan piramida makanan. Hasil penelitiannya menunjukkan bahwa 95\% responden mengatakan piramida makanan sangat berguna. Dalam tingkat piramida makanan vegetarian, kacang-kacangan dan makanan pengganti daging serta kelompok susu dan produknya di konsumsi lebih sedikit dibanding dengan sayur-sayuran dan buahbuahan. Bagi vegetarian lacto-ovo yang masih mengonsumsi susu kedelai maupun hasil olahan kedelai lainnya yang telah di fortifikasi dengan vitamin B12 (Department of Nutrition Loma Linda University, 2008).

Penelitian lain yang dilakukan oleh Choi, Atkinson, Karlson, Willett dan Curhan (2004), menunjukkan bahwa dampak dari purin produksi nabati berbeda dengan dampak purin produksi hewani. Purin dari daging dan ikan meningkatkan resiko penyakit gout, sementara purin dari sayuran bukan merupakan faktor resiko. Penelitian epidemiologi ini menjelaskan bahwa 
semua makanan yang mengandung purin tidak sama dan jumlah purin dari produk nabati lebih aman dari pada jumlah purin dari produk hewani yang dapat meningkatkan resiko penyakit gout.

Faktor - faktor terjadinya asam urat:

\section{Penyakit ginjal kronis}

Ginjal merupakan filter berbagai benda asing untuk diekskresi keluar tubuh. Karena itu, gangguan yang timbul pada organ ini akan memengaruhi metabolisme tubuh dan menimbulkan berbagai jenis penyakit. Salah satunya penyakit yang bisa ditimbulkan adalah hiperurisemia. Hiperurisemia dan penyakit ginjal memiliki hubungan sebab akibat. Gangguan fungsi ginjal bisa mengganggu eskresi asam urat. Namun, kadar asam urat yang terlalu tinggi juga bisa mengganggu kinerja dan fungsi ginjal (Lingga, 2012). Asam urat dikeluarkan bersama urin melalui ginjal. Jika terjadi gangguan pada ginjal, pengeluaran asam urat juga terganggu (Harlinawati, 2008).

\section{Faktor usia}

Asam urat umumnya dialami oleh pria dan wanita dewasa yang berusia diatas 40 tahun. Setelah memasuki masa pubertas, pria memiliki resiko asam urat lebih tinggi dibandingkan dengan wanita. Jumlah total penderita asam urat pada pria lebih banyak dibandingkan dengan kaum wanita. Ketika memasuki usia paruh baya, jumlahnya menjadi sebanding antara pria dan wanita. Dalam sebuah kajian di Amerika, prevalensi berlipat ganda dalam populasi usia 40-75 tahun. Dalam kajian kedua, prevalensi gout pada populasi dewasa di Inggris diperkirakan sebesar $1.4 \%$, dengan puncaknya lebih dari $7 \%$ pada pria usia 40-75 (Beyond, 2010 dalam Lingga, 2012). Menurut survey yang diadakan oleh National Health and Nutrition Examinition Survey (NHANES), rasio penderita hiperurisemia sebagai berikut: usia di atas 20 tahun ada $24 \%$, usia 50-60 tahun ada 30\%, usia lebih dari 60 tahun ada $40 \%$ dan rata-rata penduduk Asia mencapai 5-6\%. Resiko serangan asam urat mencapai puncaknya pada saat seseorang berusia 75 tahun, setelah berusia di atas 75 tahun, resiko asam urat semakin menurun, bahkan tidak ada resiko sama sekali. Kecuali, jika penyakit tersebut merupakan perkembangan dari penyakit asam urat kronis yang sebelumnya telah dialami (Lingga, 2012). Menurut Harlinawati (2008) penyakit asam urat lebih sering menyerang pria di atas 30 tahun. Hal ini disebabkan pria mempunyai kandungan asam urat dalam darah lebih tinggi dibanding wanita. Kandungan asam urat pada wanita baru meningkat selelah menopause. Hal tersebut tidak terlepas dari peran hormon estrogen pada wanita yang mampu menurunkan kadar asam urat dan memperlancar pembuangannya melalui ginjal.

\section{Dehidrasi}

Kekurangan cairan didalam tubuh akan menghambat ekskresi asam urat. Pada dasarnya semua cairan itu adalah pelarut. Namun, daya larut setiap cairan berbeda-beda. Air yang memiliki daya larut paling tinggi adalah air putih. Air putih dapat melarutkan semua zat yang larut di dalam cairan, termasuk asam urat. Air diperlukan sebagai pelarut asam urat yang dibuang atau diekskresi melalui ginjal bersama urine. Jika 
tubuh kekurangan air, maka akan menghambat ekskresi asam urat sehingga memicu peningkatan asam urat. Saat volume cairan tubuh kurang, maka sampah sisa metabolisme pun akan menumpuk. Penumpukan asam urat dan sisa metabolisme itulah yang menimbulkan nyeri di persendian (Lingga, 2012). Kurang minum memicu pengendapan asam urat dan menghambat pengeluaran asam urat (Harlinawati, 2008).

\section{Makan purin berlebihan}

Asupan purin dari makanan akan menambah jumlah purin yang beredar di dalam tubuh. Secara teknis, penambahan purin yang beredar di dalam darah tergantung pada jumlah purin yang berasal dari makanan. Artinya, semakin banyak mengkonsumsi purin, semakin tinggi kadar asam urat (produk akhir metabolisme purin) dalam tubuh (Lingga, 2012). Purin merupakan senyawa yang akan diubah menjadi asam urat dalam tubuh. Kadar asam urat meningkat karena asupan makanan tinggi purin. Jenis makanan yang tinggi purin, misalnya jeroan, seafood, makanan kaleng, dan kaldu daging (Harlinawati, 2008).

\section{Konsumsi alkohol}

Sejumlah studi mengatakan konsumsi alkohol memiliki pengaruh sangat besar dalam meningkatkan prevalensi asam urat pada penggemar alkohol. Dampak buruk alkohol akan semakin nyata pada individu yang mengalami obesitas. Sebuah studi yang dilakukan di Jepang oleh Shirusi (2009) menemukan korelasi nyata antara konsumsi alkohol dan obesitas terhadap hiperurisemia. Resiko konsumsi alkohol semakin tinggi jika dilakukan oleh penderita obesitas yang gemar mengkonsumsi akohol (Lingga, 2012).

Alkohol merupakan penghambat pengeluaran asam urat dari dalam tubuh. Mengonsumsi minuman keras akan meningkatkan produksi asam urat di dalam hati. Jenis minuman keras yang paling harus diwaspadai untuk menghindari serangan penyakit asam urat adalah bir dan spirit. Minuman keras ini mengandung purin yang tinggi. Untuk wine, tidak meningkatkan risiko terkena penyakit asam urat secara signifikan asalkan diminum hanya satu atau dua gelas perhari (Harlinawati, 2008).

\section{Paska operasi}

Seseorang yang telah menjalani operasi beresiko mengalami kenaikan kadar asam urat sesaat. Karena penurunan jumlah air yang mereka konsumsi paska operasi menyebabkan ekskresi asam urat terhambat untuk sementara waktu (Lingga, 2012).

Patofisiologi Proses perjalanan penyakit asam urat harus melalui tahapan-tahapan tertentu yang menandai perjalanan penyakit ini. Gejala awal ditandai oleh hiperurisemia kemudian berkembang menjadi asam urat dan komplikasi yang ditimbulkannya. Prosesnya berjalan cukup lama tergantung kuat atau lemahnya faktor resiko yang dialami oleh seorang penderita hiperurisemia. Jika hiperurisemia tidak ditangani dengan baik, cepat atau lambat penderita akan mengalami serangan asam urat akut. Jika kadar asam urat tetap tinggi selama beberapa tahun, penderita tersebut akan mengalami 
stadium interkritikal. Setelah memasuki fase ini, tidak butuh waktu lama untuk menuju fase akhir yang dinamakan dengan stadium asam urat kronis (Lingga, 2012).

Penyakit asam urat termasuk dalam golongan penyakit rematik (artitis gout). Penyakit ini disebabkan oleh penumpukan asam urat (monosodium urat) yang masuk ke dalam rongga sendi. Asam urat terbentuk jika tubuh mengkonsumsi makanan yang banyak mengandung purin.

Purin dalam bahan pangan, terdapat dalam asam nukleat berupa nukleoprotein. Ketika di konsumsi, di dalam usus, asam nukleat ini akan dibebaskan dari nukleoprotein oleh enzim pencernaan. Selanjutnya, asam nukleat dipecah menjadi purin dan pirimidin. Purin teroksidasi menjadi asam urat.

Jika pola makan tidak dirubah, kadar asam urat dalam darah yang berlebihan akan menimbulkan menumpuknya kristal asam urat. Apabila kristal terbentuk dalam cairan sendi, maka akan terjadi penyakit asam urat. Lebih parah lagi jika penimbunan ini terjadi dalam ginjal, tidak menutup kemungkinan akan menumpuk dan menjadi batu asam urat (batu ginjal) (Mulyatno, 2016).

Asam urat merupakan limbah yang terbentuk dari pemecahan zat purin yang ada di dalam sel-sel tubuh. Setiap harinya, asam ini dibuang dari tubuh kita melalui ginjal. Jika asam urat yang dibuang dari tubuh jauh lebih sedikit dari jumlah produksinya, maka sisanya akan menumpuk di dalam dan sekitar sendi dalam bentuk kristal-kristal tajam natrium urat. Pembentukan dan penumpukan kristal-kristal tersebut bisa berlangsung selama bertahuntahun tanpa kita sadari. Beberapa kristal yang bertumpuk akan keluar dari tulang rawan dan membuat lapisan lembut pada sendi yang disebut sinovium dan mengalami radang yang terasa menyakitkan. Ketika ini terjadi, itu berarti penderita sedang mengalami serangan asam urat. Pada akhirnya, kristal yang tertumpuk akan membentuk gumpalan keras yang disebut tofi. Tofi ini bisa menyebabkan kerusakan pada tulang rawan sendi dan tulang di sekitarnya. Jika tidak segera ditangani, bisa mengarah pada kerusakan sendi permanen dan jika sudah seperti ini, sendi akan terasa kaku dan sakit ketika digerakkan (Nettina, 2011).

Tanda dan gejala

Penderita penyakit ini kesulitan untuk berjalan akibat rasa sakit yang sangat mengganggu. Gejala seringkali terasa di malam hari. Sendi yang tiba-tiba terasa sangat sakit (terutama sendi jempol kaki) merupakan gejala penyakit asam urat yang paling umum. Sendi-sendi yang rawan serangan penyakit asam urat yaitu: pergelangan kaki, kaki bagian tengah, lutut, pergelangan tangan, jari tangan, siku (Junaidi, 2013).

Gejala penyakit asam urat yaitu:

1. Pembengkakan di dalam dan di sekitar sendi yang mengalami radang.

2. Kulit di atas sendi yang terlihat memerah dan mengilap.

3. Rasa sakit yang tidak tertahankan terutama ketika sendi tersentuh benda apa pun, 
bahkan jika tersentuh selimut sekali pun.

4. Saat radang pada sendi mereda, kulit pada area tersebut terlihat mengelupas dan terasa gatal.

Kadar asam urat normal menurut WHO:

1. Pada laki-laki dewasa kadar normal asam urat yaitu sekitar 2 $-7,5 \mathrm{mg} / \mathrm{dL}$, sementara itu pada wanita yang sudah dewasa yaitu $2-6,5 \mathrm{mg} / \mathrm{dL}$.

2. Pada laki-laki dengan usia diatas 40 tahun kadar normal asam urat $2-8,5 \mathrm{mg} / \mathrm{dL}$, pada wanita $2-8 \mathrm{mg} / \mathrm{dL}$

3. Anak-anak yang berusia $10-18$ tahun kadar asam urat 3,6 - 5,5 $\mathrm{mg} / \mathrm{dL}$, sementara itu pada anak wanita $3,6-4 \mathrm{mg} / \mathrm{dL}$

Daftar makanan tinggi purin, Salma (2014):

\begin{tabular}{|l|l|}
\hline Makanan & $\begin{array}{l}\text { Asam Urat } \\
(\mathrm{mg} / 100 \mathrm{~g})\end{array}$ \\
\hline Teobromin (kafein cokelat) & 2300 \\
\hline Limpa domba/kambing & 773 \\
\hline Hati sapi & 554 \\
\hline Ikan sarden & 480 \\
\hline Jamur kuping & 448 \\
\hline Limpa sapi & 444 \\
\hline Daun melinjo & 366 \\
\hline Paru-paru sapi & 339 \\
\hline Kangkung, bayam & 290 \\
\hline Ginjal sapi & 269 \\
\hline Jantung sapi & 256 \\
\hline Hati ayam & 243 \\
\hline Jantung domba/kambing & 241 \\
\hline Ikan teri & 239 \\
\hline Udang & 234 \\
\hline Biji melinjo & 222 \\
\hline
\end{tabular}

\begin{tabular}{|l|l|}
\hline Daging kuda \& kacang & 200 \\
\hline $\begin{array}{l}\text { Kedelai } \\
\text { kacangan }\end{array}$ & 190 \\
\hline Dada ayam dg kulit & 175 \\
\hline Daging ayam & 169 \\
\hline Daging angsa & 165 \\
\hline Lidah sapi & 160 \\
\hline Ikan Kakap & 160 \\
\hline Tempe & 141 \\
\hline Daging bebek & 138 \\
\hline Kerang & 136 \\
\hline Udang Lobster & 118 \\
\hline Tahu & 108 \\
\hline
\end{tabular}

Menurut Mulyatno (2016) makanan untuk diet asam urat terbagi tiga jenis, yaitu bahan makanan yang tinggi purin, kandungan purin sedang dan rendah: Kandungan tinggi Purin (150-1000 $\mathrm{mg} / 100 \mathrm{~g}$ bahan pangan): Ikan teri, otak, jeroan, daging angsa, burung dara, telur ikan, kaldu, sarden, alkohol, ragi dan makanan yang diawetkan

Kandunga sedang purin (50-100 $\mathrm{mg} / 100 \mathrm{~g}$ bahan pangan): Ikan tongkol, tenggiri, bawal, bandeng, daging sapi, daging ayam, kerang, asparagus, kacang-kacangan, jamur, bayam, kembang kol, buncis, kapri, tahu, tempe. Bahan pangan ini sebaiknya dibatasi $50 \mathrm{~g} / \mathrm{hari}$.

Kandungan rendah purin (0-100 mg/100 g bahan pangan): Nasi, roti, makaroni, mi, crackers, susu, keju, telur, sayuran dan buah buahan kecuali durian dan alpukat.

\section{METODE PENELITIAN}

Desain penelitian menggunakan case control dengan metode purposive sampling, yaitu memilih 37 responden dengan pola makan vegetarian dan 37 reponden dengan non vegetarian 
berdasarkan pola makan yang berdomisili di Minahasa. Penelitian ini menggunakan uji statistik. T-test independent untuk melihat perbedaan kadar asam urat antara kedua kelompok dan ANOVA untuk analisis berdasarkan pola makan.

Instrument dalam penelitian ini yaitu alat ukur asam urat dengan merek Autocheck (KEMENKES RI AKL 20101311321), alkohol swabs dan kuesioner berdasarkan teori yang ada. Dalam kuesioner ada pilihan kelompok makanan yaitu kandungan makanan yang tinggi purin, kandungan makanan sedang purin dan kandungan makanan rendah purin.

Dalam proses pengumpulan data dilakukan dengan langkah-langkah sebagai berikut: (1) Mengetahui dengan pasti bahwa partisipan mempunyai pola makan vegetarian dan tidak vegetarian (2) Memberitahukan maksud dan tujuan penelitian kepada partisipan. (3) Menandatangi informed consent bila bersedia menjadi responden. (3) Melakukan pengisian kuesioner dan pengambilan sampel nilai asam urat di ujung jari. (4) Ucapan terima kasih kepada responden. (5) Tabulasi dan pengolahan data. Presentasi, Analisa dan Interpretasi Data Penelitian

Analisa dan interpretasi data penelitian telah melalui program statistik yang bertujuan untuk menjawab perumusan masalah.
Tabel 1 Kadar asam urat per group

\section{Group Statistics}

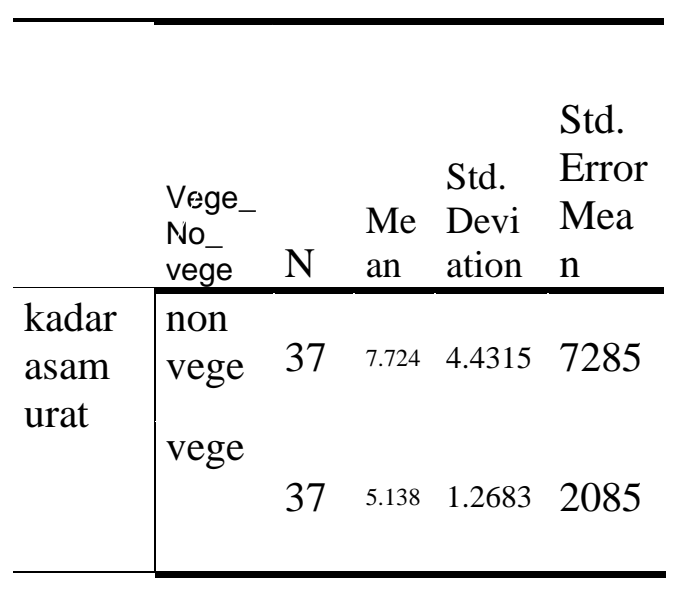

Tabel 1 menunjukkan kadar asam urat pada kelompok non-vegetarian (37 orang) dengan nilai mean 7.724 dan kelompok vegetarian (37 orang) dengan nilai mean sebesar 5.138. 
Tabel 2 Analisis Perbedaan kadar asam urat group vegetarian dan non-vegetarian

\section{Independent Samples Test}

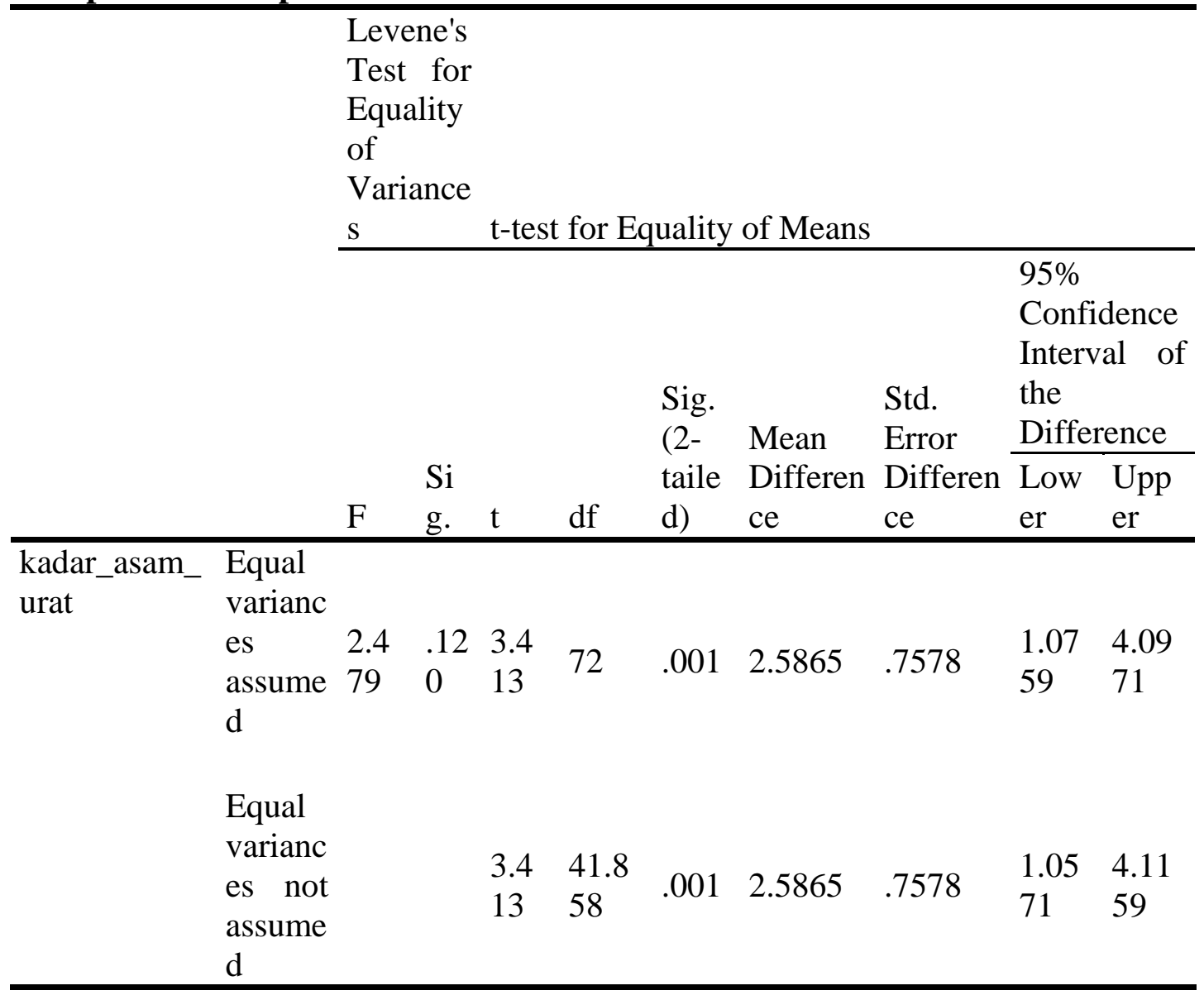

Tabel 2 menunjukkan data kadar asam urat antara kelompok vegetarian dan kelompok non-vegetarian dengan nilai $p$ value $=0,001<0,05$ yang artinya terdapat perbedaan yang signifikan kadar asam urat pada kelompok vegetarian dan non-vegetarian.
Hasil ini sesuai dengan penelitian yang dilakukan oleh Hapendatu, Assa dan Paruntu (2016) dimana hasilnya sekitar $72 \%$ responden yang vegetarian memiliki kadar asam urat dalam batas normal. 
Tabel 3 Data berdasarkan pola makan (one-way ANOVA)

Descriptives

kadar_asam_urat

\begin{tabular}{|c|c|c|c|c|c|c|c|c|}
\hline & \multirow[b]{2}{*}{$\mathrm{N}$} & \multirow[b]{2}{*}{ Mean } & \multirow[b]{2}{*}{$\begin{array}{l}\text { Std. } \\
\text { Deviation }\end{array}$} & \multirow[b]{2}{*}{$\begin{array}{l}\text { Std. } \\
\text { Error }\end{array}$} & \multicolumn{2}{|c|}{$\begin{array}{l}95 \% \text { Confidence } \\
\text { Interval for Mean }\end{array}$} & \multirow[b]{2}{*}{ Minimum } & \multirow[b]{2}{*}{ Maximum } \\
\hline & & & & & $\begin{array}{l}\text { Lower } \\
\text { Bound }\end{array}$ & $\begin{array}{l}\text { Upper } \\
\text { Bound }\end{array}$ & & \\
\hline sedang & 56 & 6.473 & 3.8402 & .5132 & 5.445 & 7.502 & 3.1 & 32.0 \\
\hline rendah & 18 & 6.300 & 2.1302 & .5021 & 5.241 & 7.359 & 3.5 & 10.9 \\
\hline Total & 74 & 6.431 & 3.4890 & .4056 & 5.623 & 7.239 & 3.1 & 32.0 \\
\hline
\end{tabular}

Tabel 3 menunjukkan pada kelompok pola makan yang mengandung sedang purin (frequency 56 orang) dengan nilai mean 6.473 dan kelompok pola makan yang mengandung rendah purin (frequency 18 orang) dengan nilai mean 6.300 .

Tabel 4 Analisis berdasarkan pola makan

\begin{tabular}{llllll}
\multicolumn{1}{l}{ ANOVA } \\
\hline kadar_asam_urat \\
\hline $\begin{array}{l}\text { Sum of } \\
\text { Squares }\end{array}$ & df & $\begin{array}{l}\text { Mean } \\
\text { Square }\end{array}$ & F & Sig. \\
\hline $\begin{array}{llllll}\text { Between } \\
\text { Groups }\end{array}$ & .409 & 1 & .409 & .03 & .85 \\
& & & & \\
Within & 888.2 & 72 & 12.33 & & \\
Groups & 50 & 72 & 7 & & \\
\hline Total & 888.6 & 73 & & & \\
& 59 & 73 & & & \\
\hline
\end{tabular}

Tabel 4 menunjukkan kadar asam urat berdasarkan pola makan dengan nilai $p$ value $=0,856>0,05$ yang artinya tidak ada perbedaan yang signifikan kadar asam urat berdasarkan pola makan.
Hasil ini sesuai dengan penelitian yang dilakukan oleh Himma dan Subagio (2008), dimana didapati bahwa tidak ada hubungan antara asupan makanan yang mengandung purin dengan vegetarian. Umumnya responden mengkonsumsi jenis makanan seperti ikan, ayam, tahu, tempe, kacangkacangan, asparagus, bayam, daun singkong, kangkung, daun \& biji melinjo. Banyak sumber purin yang di konsumsi berasal dari nabati dan produk nabati merupakan produk makanan yang berasal dari tumbuhan. Selain itu gaya hidup dan olahraga juga mengambil peranan penting dalam stabilnya asam urat. Olaharaga rutin yang dilakukan dapat berdampak baik bagi kesehatan fisik, sedangkan olahraga yang tidak rutin dilakukan akan memicu terjadinya penyakit kronis dikemudian hari.

\section{KESIMPULAN}

Hasil penelitian terhadap 37 responden pada kelompok vegetarian dan 37 responden pada kelompok nonvegetarian di Minahasa didapati bahwa terdapat perbedaan yang signifikan kadar asam urat pada kelompok 
vegetarian dan non-vegetarian, dan tidak ada perbedaan yang signifikan kadar asam urat berdasarkan pola makan pada kedua kelompok ini.

\section{Rekomendasi}

Makanan yang dikonsumsi sehari-hari mengandung jumlah purin yang tidak sama, dan sangat dianjurkan supaya mengkonsumsi makanan dari produk nabati daripada produk hewani yang dapat meningkatkan resiko penyakit asam urat (gout). Penelitian selanjutnya untuk dapat menambah jumlah responden.

\section{DAFTAR PUSTAKA}

Bangun A. (2003). Vegetarian Pola Hidup Sehat Berpantang Daging. Jakarta: Agromedia Pustaka

Choi, H.K., K. Atkinson, E.W. Karlson, W. Willett \& G. Curhan. (2004). Purine-rich foods, dairy and protein intake, and the risk of gout in men. $N$ Engl $\mathrm{J} \mathrm{Med,}$ 350 (11):1093-103.

Craig WJ, Mangels AR. (2009). Position of the American Dietetic Association Vegetarian Diet. Jurnal of the Amerian Dietetic Association, 109:74865.

Department of Nutrition Loma Linda University. (2008) The vegetarian food pyramid. www.vegetariannutrition.org/fo od-pyramid.pdf.
Halinawati K.A.S. 2008. Terapi Jus untuk rematik dan Asam Urat, Cetakan V. Jakarta: Puspa Swara, Anggota IKAPI

Hapendatu.C. P, Assa.Y.A.\& Paruntu.M.E. (2016). Gambaran asam urat serum pada vegetarian Lacto-ovo. EJournal Universitas Sam Ratulangi, Vol 4, No 1.

Himma A. \& Subagio HW. (2008). Asupan karbohidrat, lemak, protein, makanan sumber purin dan kadar asam urat. Fakultas Kedokteran Universitas Diponegoro, Semarang. Skripsi.

Junaidi, I. (2013). Rematik dan Asam Urat. Jakarta: Bhuana Ilmu Populer

Lingga, L. (2012). Bebas Penyakit Asam Urat Tanpa Obat. Jakarta: Agro Media Pustaka

Naga, S. (2013). Ilmu Penyakit Dalam. Jakarta: Diva Press

Kanbara, A., Hakoda, M., Seyama I. (2010). Urine Alkalization facilitates uric Acid Excretion. Nutritional Journal, 9: 45 doi 10.1186/1475-289145.

Mulyatno K.C. (2016). Institiute of Tropical Disease (ITD). Universitas Airlangga

Nettina S.M. (2011). Lippincott's pocket manual of nursing practice. Philadelphia: Lippincott 
Salma.(2014).http://majalahkesehatan. com/pantangan-dan-anjuranbagi-penderita-asam-urat/

Setriani. A,, Utari DM., Mardatilah, Wahyu K.Y. Putra, \& Sudiarti T. (2013). Development of food pyramid for vegetarian in Indonesia, vol.1.
Wurangian, V.G., Kepel, B., \& Manampiring, A. (2013). Gambaran Asam Urat pada Remaja Obes di Kabupaten Minahasa. Bagian Kimia Fakultas Kedokteran Universitas Sam Ratulangi. Skripsi. Published. 